\title{
SURGICAL TREATMENT OF TRAUMATIC ESOPHAGEAL PERFORATIONS. ANALYSIS OF 10 CASES
}

\author{
Rafael Andrade-Alegre
}

Andrade-Alegre R. Surgical treatment of traumatic esophageal perforations. analysis of 10 cases. Clinics. 2005;60(5):375-80.

PURPOSE: Traumatic esophageal perforations are infrequent. They represent a surgical dilemma for surgeons, especially if diagnosis is made late. Recently, it has been reported that mortality due to perforation of the esophagus has diminished independently of time of presentation. The experience with traumatic perforations of the esophagus is reviewed to determine morbidity-mortality and how it is affected by time.

METHODS: A retrospective clinical review was made of all patients with a diagnosis of traumatic perforation of the esophagus treated by the author. There were 10 patients, all of them male. Average age was 32 years (range 17 to 63). The cause of trauma was gunshot (7), blunt trauma (1) and foreign body (2). Four patients were treated within 24 hours of injury (early treatment). Treatment of 6 patients was delayed 56 to 168 hours after the injury (delayed treatment). RESULTS: Patients treated early underwent primary repair. Delayed treatment included: primary repair (1), T-tube (2), drainage of cervical abscess and pulmonary decortication (2), and conservative treatment (1). There was 1 death in the delayed group (16.6\%). One patient in the early treatment group $(25 \%) ; 4(66 \%)$ in the delayed treatment group had complications. Postoperative stay in the hospital was an average of 20.5 days for the early treatment group and 38 for the late treatment group.

CONCLUSIONS: Mortality of traumatic esophageal perforations has diminished significantly. Morbidity, particularly in delayed treatment, is still very high, with multiple operations and prolonged stays in intensive care units and surgical wards, resulting in high hospital costs. The main factor that seems to influence mortality-morbidity of traumatic esophageal perforations is the time of diagnosis. Every effort should be made to diagnose these injuries early. Once diagnosis is made, treatment should be aggressive and expeditious.

KEYWORDS: Esophageal trauma. Esophageal perforation. Delayed perforation treatment. Diagnosis. Treatment.

Traumatic esophageal perforations are infrequent. In the 1980s, Bladergroen ${ }^{1}$ reported 127 cases of esophageal perforations during a period of 47 years. Only $24 \%$ corresponded to traumatic perforations. In the same decade, Cheadle $^{2}$ reported 19 cases of traumatic esophageal perforations treated over a period of 10 years. Recently, Asensio ${ }^{3}$ presented the third largest series of traumatic esophageal perforations: 43 cases in 6 years. Traditionally it has been said that treatment of perforations after a delay of more

Thoracic Surgery Section, Santo Tomás Hospital - Panamá, Republic of Panamá.

Email: toravasc@cwpanama.net

Received for publication on March 30, 2005.

Accepted for publication on June 13, 2005. than 24 hours results in a high morbidity and mortality rate. ${ }^{4-8}$

During the 1990s, several papers appeared stating that mortality for esophageal perforations had diminished whether treated early or after a delay.,10

A retrospective review of the experience with 10 consecutive cases of traumatic esophageal perforations is presented here in order to evaluate how time of treatment affects morbidity and mortality.

\section{METHODS}

This is a retrospective-descriptive study of all the traumatic esophageal perforations treated by the author. Ten 
cases were treated between August 1992 and July 2003. All the patients were male, and the average age was 32 years (range 17 to 63 ). The information gathered from patient records included revised trauma score (RTS), injury severity score (ISS), mechanism of esophageal perforation, area of esophageal perforation, time elapsed between injury and operation, diagnostic method, surgical procedures, complications, mortality, intensive care unit (ICU) days, and total postoperative stay in the hospital. Cost variables including ICU and ward days costs were recorded according to the Cost Office of Santo Tomás Hospital .

\section{RESULTS}

The etiology of the perforations was gunshot wound (7), blunt trauma (1), and foreign body (2).

Regarding the location of the perforations, 5 were cervical and 5 were thoracic. The average RTS was 7.45 (range 6.61 to 7.84 ). The average ISS was 23 (range 16 to 32). Four patients were treated early and underwent primary repair (interrupted sutures). Diagnosis, surgical procedures, associated lesions, complications, and days in the hospital are summarized in Table 1.

Six patients had a delayed diagnosis. Of these, 3 were referred from other hospitals and 2 were referred from other surgical services in our own hospital. These patients had a time interval of between 56 and 168 hours from the occurrence of perforation to treatment. Findings at surgery, surgical procedures, complications, and days in the hospital are summarized in Table 2 . The 4 early treated patients survived. One was complicated with chemical pneumonitis as the patient had a traumatic tracheoesophageal fistula from aspirating the water-soluble contrast medium used in the esophagogram (Fig. 1). An additional complication was recorded in another patient not related to the esophageal injury. The patient had a severe right pulmonary contusion and hemoptysis due to a gunshot wound for which he required independent pulmonary ventilation (Fig. 2). He developed pneumonia.

The average hospital stay for these patients was 20.5 days. Discounting the patient who required prolonged mechanical ventilation associated with the pulmonary contusion, the hospital stay was reduced to an average 18 days. Still more important is the fact that the stay in the ICU averaged only 2.3 days. Cost per patient averaged $\$ 5280$. It is important to stress that there was no leakage at the suture line in any patient.

In the group having delayed diagnosis and treatment, only 2 patients did not have complications. The 4 other patients had major complications: pneumonia (2), chronic empyema (3), acute renal insufficiency (1), sepsis (1), central venous catheter (CVC) sepsis (1), and tracheoesophageal fistula (1). On the whole, there were 2.25 complications per patient. These patients stayed in the hospital between 10 and 83 days (average 38 ). The ICU stay varied between 0 and 26 days (average 12.25 ). The cost per patient averaged $\$ 12,400$. One patient who had a tracheoesophageal fistula due to blunt chest trauma died. (Fig. 3). After the initial repair of the injuries, this patient developed another fistula and required further surgery. This second time, a pectoral muscle flap was fashioned. The initial postoperative period was satisfactory. He was started on a diet that was well tolerated but developed CVC sepsis, dying on the 83 postoperative day. The autopsy did not show any leak, fistula, or intrathoracic collections.

\section{DISCUSSION}

Traumatic esophageal perforations are infrequent, and their management has been a surgical dilemma and a challenge for surgeons. This is evident when taking into account the numerous therapeutic options described, especially for late di-

Table 1 - Early Treatment

\begin{tabular}{|c|c|c|c|c|c|}
\hline PATIENT & DIAGNOSIS & PROCEDURE & ASSOCIATED LESIONS & COMPLICATIONS & $\mathrm{DIH}$ \\
\hline $\mathrm{RS}$ & Esophagogram & $\begin{array}{l}\text { Suture of esophagus }+ \text { suture of } \\
\text { trachea }+ \text { sternocleidomastoid } \\
\text { muscle flap }\end{array}$ & Tracheal perforation $\# 2$ & 1.Chemical pneumonitis & 24 \\
\hline $\mathrm{JN}$ & $\begin{array}{l}\text { Bronchoscopy } \\
\text { Surgical exploration }\end{array}$ & $\begin{array}{l}\text { Suture of esophagus }+ \text { suture of } \\
\text { trachea }+ \text { sternocleidomastoid } \\
\text { muscle flap }+ \text { Tracheostomy }\end{array}$ & Tracheal perforation \#2 & & 17 \\
\hline $\mathrm{CC}$ & Esophagogram & $\begin{array}{l}\text { Suture of perforation of the } \\
\text { esophagus }\end{array}$ & $\begin{array}{l}\text { Severe pulmonary } \\
\text { contusion (IPV) }\end{array}$ & Pneumonia & 39 \\
\hline FS & $\begin{array}{l}\text { Thoracotomy } \\
\text { (Massive hemothorax) }\end{array}$ & $\begin{array}{l}\text { Suture of perforation of the } \\
\text { esophagus, suture of lung } \\
\text { lacerations + partial resection } \\
\text { small bowel }\end{array}$ & $\begin{array}{l}\text { Pulmonary lacerations \# } 4 \\
\text { Multiple perforations of } \\
\text { small bowel }\end{array}$ & & 14 \\
\hline
\end{tabular}

DIH: Days in hospital; IPV: Independant pulmonary ventilation 
Table 2 - Delayed Treatment

\begin{tabular}{|c|c|c|c|c|c|c|}
\hline PATIENT & TIME(HOURS) & DIAGNOSIS & FINDINGS & PROCEDURE & COMPLICATIONS & DIH \\
\hline ER & 60 & $\begin{array}{l}\text { Esophagogram (negative) } \\
\text { Esophagoscopy }\end{array}$ & $\begin{array}{l}\text { Empyema (Fase II) } \\
\text { Essophageal perforation }\end{array}$ & $\begin{array}{l}\text { T-tube +Pulmonary } \\
\text { decortication }+ \\
\text { Gastrostomy }+ \\
\text { Jejunostomy }\end{array}$ & $\begin{array}{l}\text { 1.Empyema } \\
\text { 2.Pneumonia }\end{array}$ & 31 \\
\hline $\mathrm{RP}$ & 168 & Surgical exploration & $\begin{array}{l}\text { Periesophageal abscess } \\
\text { Foreign body }\end{array}$ & $\begin{array}{l}\text { Abscess drainage }+ \\
\text { Pulmonary Decortication }\end{array}$ & $\begin{array}{l}\text { 1.Empyema } \\
\text { 2.Acute renal } \\
\text { insufficiency }\end{array}$ & 59 \\
\hline $\mathrm{SC}$ & 72 & Esophagogram & $\begin{array}{l}\text { Contained leak mid } \\
\text { esophagus-Foreign body }\end{array}$ & $\begin{array}{l}\text { Esophagoscopy }+ \\
\text { removal of foreign body }\end{array}$ & - & 10 \\
\hline$\overline{\mathrm{RPJ}}$ & 64 & Esophagogram & $\begin{array}{l}\text { Esophageal perforations } \\
\# 2 \\
\text { Perforation of } \\
\text { membranous trachea }\end{array}$ & $\begin{array}{l}\text { 1.Suture of perforation } \\
\text { of the esophagus }+ \\
\text { placement of } T \text { tube }+ \\
\text { Suture of trachea }+ \text { pleural } \\
\text { flap } \\
\text { 2. Pectoral muscle flap }\end{array}$ & $\begin{array}{l}\text { 1.Refistulization } \\
\text { 2.Central venous } \\
\text { catheter sepsis }\end{array}$ & 83(death) \\
\hline $\mathrm{JH}$ & 72 & Esophagogram & $\begin{array}{l}\text { Perforation of esophagus } \\
\text { Contained leak distal } \\
\text { esophagus }\end{array}$ & $\begin{array}{l}\text { Suture of esophageal } \\
\text { perforations }\end{array}$ & - & 12 \\
\hline $\mathrm{RR}$ & 56 & Surgical exploration & $\begin{array}{l}\text { Cervical abscess }+ \\
\text { fistula of cervical } \\
\text { esophagus }+ \\
\text { Chronic empyema }\end{array}$ & $\begin{array}{l}\text { Drainage of abscess }+ \\
\text { right thoracotomy and } \\
\text { decortication }\end{array}$ & $\begin{array}{l}\text { 1.Sepsis } \\
\text { 2.Empyema } \\
\text { 3.Pneumonia } \\
\text { 4.Esophageal } \\
\text { cervical fistula }\end{array}$ & 70 \\
\hline
\end{tabular}

DIH: Days in hospital

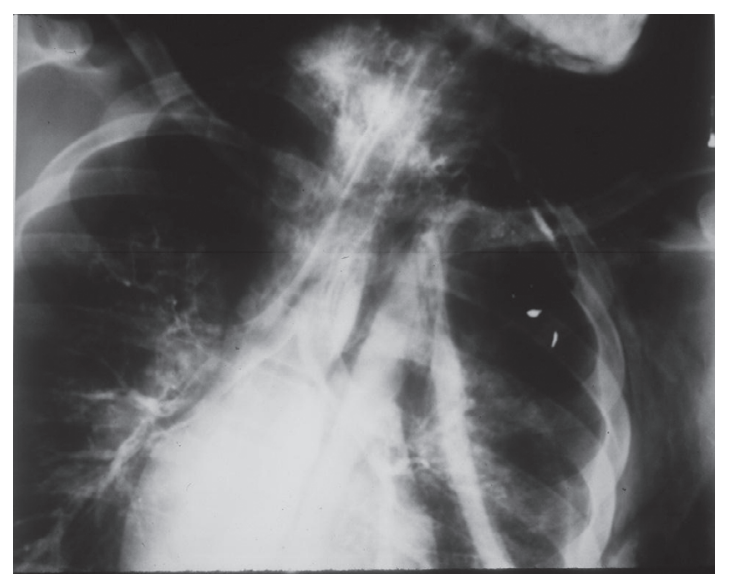

Figure 1 - Aspiration of water-soluble contrast medium during esophagogram. A gunshot wound produced a traumatic esophagotracheal fistula

agnosed perforations ${ }^{11-24}$ Most surgeons agree that delayed diagnosis and treatment increase morbidity and mortality. ${ }^{4-8}$

Diagnosis of esophageal rupture is missed if the surgeon overlooks this possibility. It is necessary to have a high index of suspicion and to proceed accordingly with the pertinent studies to confirm or rule out the presence of a perforation. Frequently, patients present injuries that are more obvious and urgent, and these can distract the surgeon's attention. For penetrating trauma, it is very important to establish the trajectory of missile/injury. In stable patients with transmediastinal injuries, a computed tomography scan is particularly helpful as it can delineate

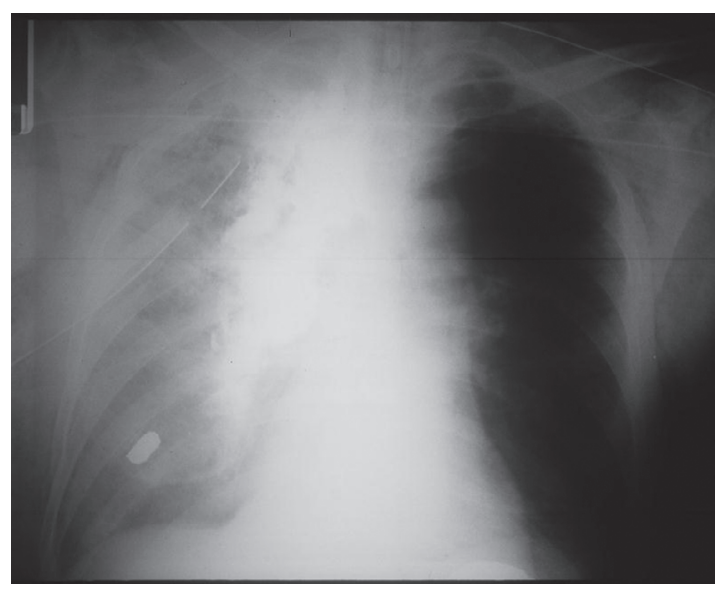

Figure 2 - Severe right pulmonary contusion and esophageal perforation. Note leak of barium into right chest

the trajectory of the missile and suggest the best diagnostic approach. ${ }^{25,26}$ In the early treatment group in this study, 2 patients were unstable and therefore were taken immediately to the operating room for urgent surgery. Diagnosis was made establishing the path of the missile. Exploration of the area is particularly important if there is a hematoma. Intraoperative endoscopy may be also useful., ${ }^{2,27}$ The other 2 patients underwent an esophagogram that confirmed the diagnosis. Use of the esophagogram should be liberal; however, several considerations have to be mentioned. Some radiologists and surgeons concerned with the possible inflammatory reaction in the mediastinum when 


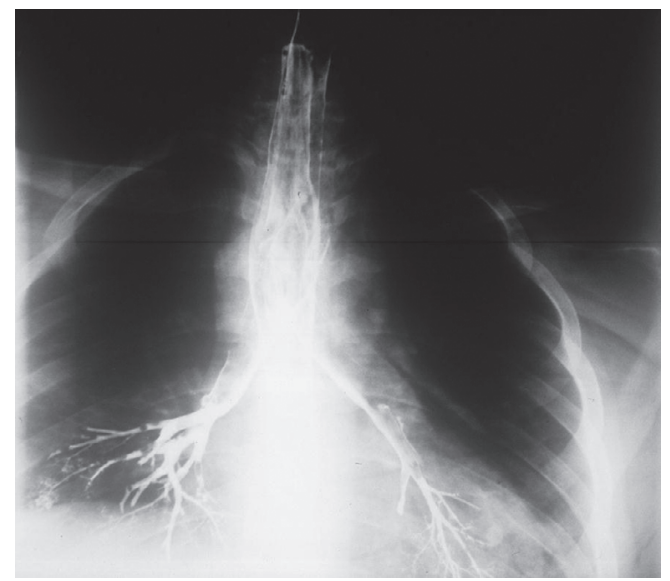

Figure 3 - Esophagotracheal fistula due to blunt trauma. Note contrast medium (barium) in the airways

barium is used, recommend the use of water-soluble contrast media. The chemical peritonitis produced by barium in the abdominal cavity is well known. This kind of reaction has not been demonstrated in the thorax ${ }^{28,29}$ (Fig.4). It is also important to mention that the osmolality of watersoluble contrast medium is around 6 times the plasma osmolality, which produces significant inflammatory reaction and respiratory distress when aspirated. ${ }^{30}$ One of our patients in this group developed chemical pneumonitis as he aspirated the water-soluble contrast medium due to a traumatic tracheoesophageal fistula. Another disadvantage of water-soluble contrast media is their inferior radiographic density and mucosal coating ability that can result in missing or inadequately demonstrating an esophageal perforation, as has been pointed out by several authors. In a comparative study, Buecker et $\mathrm{al}^{31}$ found a $22 \%$ false negative rate with water-soluble contrast media; in contrast, with barium, all the esophageal perforations were detected. In general, esophagograms can produce false negatives at a rate of between $10 \%$ and $25 \% .^{32,33}$ DeMeester $^{34}$ proposed another factor that may play a role in the false negative

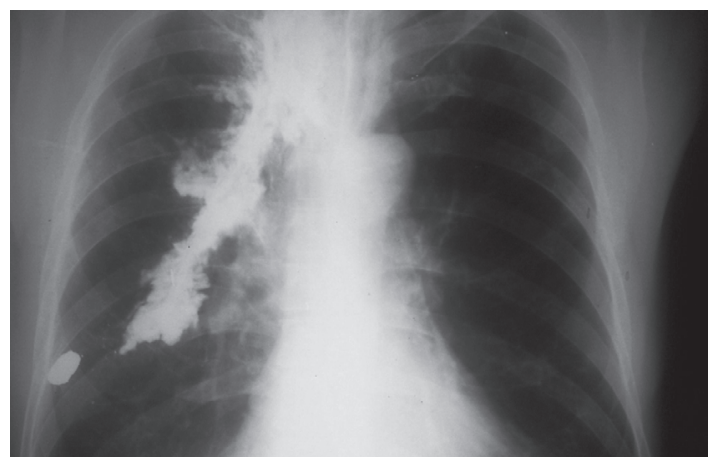

Figure 4 - Postoperative chest roentgenogram several weeks after the treatment of esophageal perforation due to a gunshot wound. No complications related to barium cases: many of these studies are performed with the patient in an upright position so that the contrast passes too quickly, allowing the perforation to be overlooked. He suggests performing some views in right or left lateral decubitus. If there is any possibility of tracheoesophageal fistula or aspiration, barium should be used instead of watersoluble contrast media. Barium should also be used every time a water-soluble contrast medium study is negative. If the esophagogram is negative and an esophageal injury is still suspected, then endoscopy should be carried out. Following this rule should reduce the incidence of delayed diagnosis of esophageal perforations.

In the early treated patients, primary repair was performed in a single layer with interrupted sutures. In the cases of associated tracheal injury, a sternocleidomastoid muscle flap was fashioned. The reinforcement of the esophageal repair helps to avoid leakage and the development of a tracheoesophageal fistula. ${ }^{35}$ This approach is also applicable when the associated injury is the carotid artery. ${ }^{36}$ None of the early treated patients presented leakage of the suture line, only 1 patient was complicated, and there was no mortality. These results are consistent with what has been reported in the medical literature for early treatment even in the presence of multiple trauma injuries or when patients are hemodynamically unstable..$^{5-7}$

The group of patients with delayed (more than 24 hours) diagnosis and treatment represent a more severe problem. In one patient, diagnosis was delayed because the esophagogram gave a false negative indication. In this case, which has been previously published, ${ }^{37}$ diagnosis was made endoscopically 60 hours after the occurrence of the perforation. The other 5 patients with delayed perforation were not managed initially by the author, as they were referrals from other hospitals or surgical services. The patients with foreign bodies were referred from rural areas with very limited medical facilities. The diagnosis of a foreign body in the esophagus was suspected by the referring physicians, but the patients arrived several days after the injury and already had esophageal perforations. Both foreign bodies were fish bones, which are one of the most common foreign bodies in the esophagus. ${ }^{38,39}$ The patient with contained perforation in the mediastinum was managed conservatively following Cameron's criteria. ${ }^{12}$ The fish bone was removed endoscopically, and the patient was kept nil by mouth and started on antibiotics and total parenteral nutrition. In my experience as well as in that of other surgeons, this approach seems to be the exception and not the rule. ${ }^{40,41}$ In the 3 remaining patients, the injury was not suspected initially and the esophagogram was not performed early. In all, $4(66 \%)$ patients with delayed diagnosis had major complications, and there was 1 death (16\%). 
Regarding the treatment of delayed esophageal perforations, some surgeons promote primary repair for most of the cases. ${ }^{10,20,42}$ Others favor an individualized approach. ${ }^{19,32,41,43}$ The surgical decision depends on several aspects including the patient's general condition, extent of damage, quality of tissues, underlying esophageal disease and the surgeon's experience. ${ }^{44}$

It is true that mortality from traumatic perforations of the esophagus has diminished since the 1990s. The results in this study support this statement. The global mortality for the 10 cases presented was $10 \%$. In the delayed treatment cases, mortality was $16 \%$. The drop in mortality rate is probably due to a more aggressive diagnostic and therapeutic approach by surgeons, advances in critical care, and better antibiotics and parenteral nutrition. ${ }^{945}$ Morbidity has not changed much for late perforations. These patients are subject to multiple procedures and long periods of time in the ICU and the surgical wards. and Hospital costs are consequently elevated.

In summary, every effort should be made to diagnose esophageal traumatic perforations as early as possible, and the treatment should be expeditious and definitive. Once a delayed diagnosis is made, surgeons must be committed to approach this problem aggressively to avoid a chronic and debilitating condition.

\section{RESUMO}

Andrade-Alegre R. Tratamento cirúrgico de perfurações esofágicas. Análise de 10 casos. Clinics. 2005;60(5):37580.

PROPÓSITO: Perfurações esofágicas não são freqüentes. Representam um dilema cirúrgico, especialmente se o diagnóstico é tardio. Relato recente dá conta que a mortalidade devida a perfuração esofágica apresenta redução independentemente de seu tempo de evolução. A experiência com perfurações esofágicas traumáticas é aqui revista para determinar a relação morbi-mortalidade e como esta é afetada pelo tempo.

MÉTODOS: Uma revisão retrospectiva clínica foi realizada para todos os pacientes com diagnóstico de perfuração esofágica traumática tratados pelo autor. Registraram-se 10 pacientes, todos do sexo masculino. I idade média foi de 32 anos (17 a 63). As causas foram arma de fogo (7), trauma contuso (1) e corpo estranho (2). Quatro pacientes foram tratados até 24 horas após o trauma (tratamento precoce), enquanto os outros 6 foram tratados 56 a 168 horas pós trauma (tratamento tardio).

RESULTADOS: Os pacientes tratados precocemente evoluíram com reparo primário. Os pacientes em

\section{REFERENCES}

1. Bladergroen MR, Lowe JE, Postlethwait. Diagnosis and recommended management of esophageal perforation and rupture. Ann Thorac Surg. $1986 ; 42: 235-9$

2. Cheadle W, Richardson JD. Options in management of trauma to the esophagus. Surg Gynecol Obstet. 1982;155:380-4.

3. Asensio JA, Berne J, Demetriades D, Murray J, Gomez H, Falabella A, et al. Penetrating esophageal injuries: Time interval of safety for preoperative evaluation How long is safe? J Trauma. 1997;42:319-24. tratamento tardio incluíram: reparo primário $(\mathrm{n}=1)$, tubo$\mathrm{T}(\mathrm{n}=2)$, drenagem de abscesso cervical e decorticação pulmonar $(n=2)$, tratamento conservador $(n=1)$. Foi registrado 1 óbito no grupo tardio $(16,6 \%)$. Um paciente no grupo precoce $(25 \%)$ e $4(66 \%)$ no grupo tardio registraram complicações. O tempo médio de permanência hospitalar pós-operatória foi de 20.5 dias para o grupo precoce e de 38 dias para grupo tardio.

CONCLUSIONS: A mortalidade resultante de perfurações esofágicas traumáticas reduziu-se significativamente. A morbidade permanece elevada, especialmente em pacientes tratados tardiamente, com cirurgia múltipla e períodos prolongados de hospitalização em unidades de terapia intensiva e enfermarias cirúrgicas, do que resultam elevados custos hospitalares. Aparentemente, o principal fator responsável pela morbi-mortalidade é o tempo de diagnóstico. Todos os esforços deveriam ser investidos no diagnóstico precoce. Uma vez feito o diagnóstico, o tratamento deve ser urgente e agressivo.

\section{UNITERMOS: Trauma esofágico. Perfurações esofágicas. Tratamento tardio de perfurações. Diagnóstico. Tratamento.}

4. Michel L, Grillo HC, Malt RA. Operative and nonoperative management of esophageal perforations. Ann Surg. 1981;194:57-63.

5. Nesbitt JC, Sawyers JL. Surgical management of esophageal perforation. Am Surg. 1987;53:183-91.

6. White RK, Morris DM. Diagnosis and management of esophageal perforations. Am Surg. 1992;58:112-9.

7. Asensio JA, Chawan S, Forno W, McKersie R, Matthew W, Lake J, et al Penetrating esophageal injuries: multicenter study of the American Association for the surgery of trauma. J Trauma. 2001;50:289-96. 
8. Macrí P, Jiménez MF, Novoa N, Varela G. Análisis descriptivo de una serie de casos diagnosticados de mediastinitis aguda. Arch Bronconeumol. 2003;39:428-30.

9. Reeder LB, DeFilippi VJ, Ferguson MK. Current results of therapy for esophageal perforation. Am J Surg. 1995;169:615-7.

10. Port JL, Kent PJ, Korst RJ, Bacchetta M, Altorki NK. Thoracic esophageal perforations: a decade of experience. Ann Thorac Surg. 2003;75:1071-4

11. Urschel HC, Razzuk MA, Wood RE, Galbraith N, Pockey M, Paulson DL. Improved management of esophageal perforation: exclusion and diversion in continuity. Ann Surg. 1974;179:587-91.

12. Cameron JL, Kieffer RF, Hendrix TR, Mehigan DG, Baker RR. Selective nonoperative management of contained intrathoracic esophageal disruptions. Ann Thorac Surg. 1979;27:404-8.

13. Santos GH, Frater RW. Transesophageal irrigation for the treatment of mediastinitis produced by esophageal rupture. J Thorac Cardiovasc Surg. 1986;91:57-62.

14. Naylor AR, Walker WS, Dark J, Cameron EW. T tube intubation in the management of seriously ill patients with oesophagopleural fistulae. Br J Surg. 1990;77:40-2.

15. Gouge TH, Depan HJ, Spencer FC. Experience with the Grillo pleural wrap procedure in 18 patients with perforation of the thoracic esophagus. Ann Surg. 1989;209:612-9.

16. Gayet B, Breil P, Fekete F. Mechanical sutures in perforation of the thoracic esophagus as a safe procedure in patients seen late. Surg Gynecol Obstet. 1991;172:125-8.

17. Andrade-Alegre R. Esophageal exclusion. Ann Thorac Surg. 1993;56:1218.

18. Richardson JD, Tobin GR. Closure of esophageal defects with muscle flaps. Arch Surg. 1994;129:541-8.

19. Wright CD, Mathisen DJ, Wain JC, Moncure AC, Hilgenberg AD, Grillo HC. Reinforced primary repair of thoracic esophageal perforation. Ann Thorac Surg. 1995;60:245-8.

20. Whyte RI, Iannettoni MD, Orringer MB. Intrathoracic esophageal perforation. The merit of primary repair. J Thorac cardovasc Surg. 1995;109:140-4

21. Safavi A, Wang N, Razzouk A, Gan K, Sciolaro C, Wood M, et al. Onestage primary repair of distal esophageal perforation using fundic wrap. Am Surg. 1995;61:919-24.

22. Bardaxoglou E, Manganas D, Meunier B, Landen S, Maddern GJ, Campion JP, et al. New approach to surgical management of early esophageal thoracic perforation: primary suture repair reinforced with absorbable mesh and fibrin blue. World J Surg. 1997;21:618-21.

23. Orringer MB, Stirling M. Esophagectomy for esophageal disruption. Ann Thorac Surg. 1990;49:35-43.

24. Siersema PD, Homs MY, Haringsma J, Tilanus HW, Kuipers EJ. Use of large-diameter metallic stents to seal traumatic nonmalignant perforations of the esophagus. Gastrointest Endosc. 2003;58:356-61.

25. Hanpeter DE, Demetriades D, Asensio JA, Berne TV, Velmahos G, Murray J. Helical computed tomographic scan in the evaluation of mediastinal gunshot wounds. J Trauma. 2000;49:689-94.
26. Stassen NA, Lukan JK, Spain DA, Miller FB, Carrillo EH, Richardson $\mathrm{JD}$, et al. Reevaluation of diagnostic procedures for transmediastinal gunshot wounds. J Trauma. 2002;53:635-8.

27. Flowers JL, Graham SM, Ugarte MA, Sartor WM, Rodriguez A, Gens DR, et al. Flexible endoscopy for the diagnosis of esophageal trauma. J Trauma. 1996;40:261-6.

28. Vessal K, Montali RJ, Larson SM, Chaffee V, James AE. Evaluation of barium and gastrografin as contrast media for the diagnosis of esophageal ruptures or perforations. Am J Roentgenol Radium Ther Nucl Med. 1975;123:307-19.

29. James AE, Montali RJ, Chaffee V, Strecker EP, Vessal K. Barium or gastrografin: which contrast media for diagnosis of esophageal tears? Gastroenterology. 1975;68:1103-13.

30. Dodds WJ, Stewart ET, Vlymen WJ. Appropriate contrast media for evaluation of esophageal disruption. Radiology. 1982;144:439-41.

31. Buecker A, Wein BB, Neuerburg JM, Guenther RW. Esophageal perforation: comparison of use of aqueous and barium containing contrast media. Radiology. 1997;202:683-6.

32. Flynn AE, Verrier ED, Way LW, Thomas AN, Pellegrini CA. Esophageal perforation. Arch Surg. 1989;124:1211-5.

33. Glatterer MS, Toon RS, Ellestad C, McFee AS, Rogers W, Mack JW, et al. Management of blunt and penetrating external esophageal trauma. J Trauma. 1985;24:784-92.

34. DeMeester TR. Perforation of the esophagus. Ann Thorac Surg. 1986;42:231-233.

35. Felicicano DV, Bitondo CG, Mattox KL, Romo T, Burch JM, Beall AC. Combined tracheosophageal injuries. Am J Surg. 1985;150:710-5.

36. Losken A, Rozycki GS, Feliciano DV. The use of the sternocleidomastoid muscle flan in combined injuries to the esophagus and carotid artery or trachea. J Trauma. 2000;49:815-7.

37. Andrade-Alegre R. T-tube intubation in the management of late traumatic esophageal perforations: case report. J Trauma. 1994;37:1312.

38. Nashef SA, Martigne CK, Velly JF, Couraud L. Foreign body perforation of the normal esophagus. Eur J Cardiothorac Surg. 1992;6:565-7.

39. Athanassiadi K, Gerazounis M, Metaxas E, Kalantzi N. Management of esophageal foreign bodies: a retrospective review of 400 cases. Eur J Cardiothorac Surg. 2002;21:653-6.

40. Attar S, Hankins JR, Suter CM, Coughlin TR, Sequeira A, McLaughlin JS. Esophageal perforation. Ann Thorac Surg. 1990;50:45-51.

41. Rios Zambudio A, Martínez de Haro LF, Ortiz Escandell MA, Duran H, Munitiz Ruiz V, Parrilla Paricio P. Perforaciones esofágicas. Presentación de 23 casos. Gastroenterol Hepatol. 2000;23:379-83.

42. Wang N, Razzouk AJ, Safari A, Gan K, Van Arsdell GS, Burton PM, et al. Delayed primary repair of intrathoracic esophageal perforation: is it safe? J Thorac Cardiovasc Surg. 1996;111:114-21.

43. Bufkin BL, Millar JI, Manssur KA. Esophageal perforation: emphasis on management. Ann Thorac Surg. 1996;61:1447-51.

44. Andrade-Alegre R. Esophageal perforation. Ann Thorac Surg. 1996;62:1891-2.

45. Kiernan PD, Sheridan MJ, Elster E, Rhee J, Collazo L, Fulcher T, et al. Thoracic esophageal perforations. South Med J. 2003;96:158-63. 